\section{Track the impact of Kenya's ivory burn}

Kenya's government delivered a powerful message against elephant poaching and the illegal ivory trade on 30 April by burning 105 tonnes of ivory, worth up to US $\$ 220$ million. With stockpile destruction on the rise, it is important to evaluate the impact of this strategy on elephant populations.

Since 1989, 21 countries have burned or crushed 263 tonnes of ivory - most of it (86\%) in the past 5 years (see go.nature. com/ivory). However, there is no published evidence so far that these events reduce poaching.

Destroying ivory stockpiles risks a perverse outcome: ivory becomes rarer, fetching higher prices and increasing poaching and illegal stockpiling (see M. 't Sas-Rolfes et al. Pachyderm 55, 62-77; 2014). This has prompted calls by some for a highly controlled legal ivory trade to secure elephant populations (J. F. Walker and D. Stiles Science 328, 1633-1634; 2010) - an option that ivory destruction removes.

It is therefore crucial to track the effects of Kenya's largest-ever ivory burn. Time is short and the stakes are high.

Duan Biggs ${ }^{*}$ University of Queensland, Brisbane, Australia. ancientantwren@gmail.com ${ }^{*}$ On behalf of 4 correspondents (see go.nature.com/1rt2mhe for full list).

\section{China's primates: EU can't have it all ways}

We are concerned about the prospect of China becoming a world leader in research involving non-human primates, given the country's comparatively weak regulatory system and ethical framework (see Nature 532, 281; 2016 and Nature 532, 300-302; 2016).

China's relative freedom from the "ethical pressure" you mention makes it attractive to researchers working on primates.
But animal studies that could fail the harm-benefit evaluation in many Western regulatory systems should not be allowed — or actively encouraged - to take place elsewhere. Far from putting researchers under negative ethical pressure, the project-authorization process in the European Union was set up with full input from scientists and is often held up (by them) as an appropriate safeguard to promote good quality, ethically conducted science and good animal welfare (Nature 521, 7; 2015). You cannot have it both ways.

Rather than exploiting weaker animal-research regulations, we argue that more effort should be invested in developing and validating alternative technologies to avoid or reduce the use of non-human primates.

Penny Hawkins, Paul Littlefair Royal Society for the Prevention of Cruelty to Animals, Southwater, UK.

penny.hawkins@rspca.org.uk

\section{China's primates: preserve wild species}

China is being put forward as a world leader in primate biomedical research (see Nature 532, 300-302; 2016), even while its wild populations of primates are being lost at an alarming rate because of illegal activities and poor conservation practice.

Take rhesus macaques (Macaca mulatta), the species most frequently used in biomedical research. The wild population of these primates in China was estimated at about 200,000 in 2008, with a further 40,000 kept in breeding centres (see go.nature.com/1sl2bqx). This number of captive animals has since significantly increased and may, along with the 20,000 exported each year, include individuals that were bred outside captivity (see X. Hao Cell 129, 1033-1036; 2007).

Despite the changes that China is making on paper to improve its conservation policies, the declining state of its 19 native primate species conveys a different story. These animals are disappearing because of habitat disturbance, illegal export and hunting - including for traditional medicine.

The country seems to us to be more concerned with increasing its reputation in biomedical primate research. That reputation will be boosted by the large input of government funding and by Western researchers flocking in for the reasons you mention.

China's position on

conservation issues and on primate welfare should not be skated over. Animals are not exploitable, and wild populations should not be an afterthought. Alison M. Behie, Colin P. Groves The Australian National

University, Canberra, Australia.

alison.behie@anu.edu.au

\section{Supervise Chinese environment policy}

China's latest five-year plan shifts its environmental law away from a pollution-control system and towards one that manages environmental quality (see Nature 531, 524-525; 2016). Regional efforts will now be subject to greater oversight to ensure that improvements are implemented across the country and to prevent local corruption.

Under the plan, provincial environmental-protection departments will be responsible for unifying local monitoring and inspection programmes and for eliminating protectionism in local governments (see B. Zhang and C. Cao Nature 517, 433434; 2015). China's Ministry of Environmental Protection has already established separate environmental-management departments for water, air and soil.

In my view, strict national supervision would help to keep these regional reforms on track and to make them more effective. The US Environmental Protection Agency, for example, manages pollution through permits and defined standards. Ten regional offices work with individual states to implement these regulations. The agency can revoke state programmes that fail to fulfil their responsibilities.

In China, the unified supervision of local monitoring and inspection by provincial environmental-protection departments, which then report to the ministry, is an important step towards improving environmental quality. However, each of the links in this chain must strictly enforce the regulations and work with the rest to clean up the country's environment.

Bo Zhang Information Center,

Ministry of Environmental Protection, China.

zhangbo@mep.gov.cn

Disclaimer declared (see go.nature. com/24m3usa for details).

\section{Change of identity is not in the air}

Change is indeed in the air for many butterflies - at least in their ecology, if not in their outer appearance (see 'Change is in the air' Nature 532, 403-404; 2016). However, the example you picture is not the European species Hesperia comma, but the North American Epargyreus clarus - both of which have the same vernacular name of silver-spotted skipper. Josef Settele Helmholtz Centre for Environmental Research UFZ, Halle, Germany. josef.settele@ufz.de

\footnotetext{
CORRECTION

The Correspondence by

P. Dobosz and J. Zawiła-

Niedźwiecki (Nature 532, 441;

2016) incorrectly described some Polish universities as

"engaging" anti-scientific speakers. In fact, the speakers either hired university premises or participated in discussions at university conferences.
} 